\title{
THE BRITISH LEGAL AID AND ADVICE BILL
}

In theory, equal protection of the law is a touchstone of western democracy. But individuals cannot enjoy the benefits of equal protection without effective access to the courts. ${ }^{1}$ At present, excessive litigation expenses constitute a price of admission too high for all but the economic elite. ${ }^{2}$

Some feeble attempts have been made to provide official government assistance to needy litigants. For the most part, this assistance has been confined to token in forma pauperis provisions which give permission to sue without liability for court costs. ${ }^{3}$ Unfortunately, these modest measures have

1. See Elson, The Rushcliffe Report, 13 U. of CHr. L. Rev. 131 (1946).

Although the concept of equal protection probably did not originally encompass any expectation that legal aid would or should be available to all who could not meet the financial burden of private litigation, it has become customary to use this clause in the Constitution as a hook upon which to hang the rationalization that legal aid is an affirmative governmental obligation. See, e.g., Bradway, Legal Aid Work in the Untited States, 24 J. Soc'y Comp. Leg. (3d Ser.) 49 (1942).

American courts, however, have shown a reluctance to accept this theory. In 1921 the Supreme Court made it clear that the Fourteenth Amendment did not contain a positive demand for civil legal aid. Ownbey v. Morgan, 256 U.S. 94, 112 (1921). Simjlarly, state constitutions have been found to contain no positive demand for legal aid in civil cases. Jacoby, Legal Aid to the Poor, 53 HaRv. L. Rev. 940, 941 (1940). The Rhode Island Constitution, which has been interpreted to exempt poor plaintiffs from furnishing security for costs, is an exception to this general rule. See, e.g., Lewis v. Smith, 21 R.I. 324, 326, 43 Atl. 542, 543 (1899); Spalding v. Bainbridge, 12 R.I. 244 (1879). In capital cases, however, the United States Supreme Court has found that the right to counsel is included in the broad language of the Fourteenth Amendment's due process clause. Powell v. Alabama, 287 U.S. 45, 68 (1932).

It is interesting to note that the Swiss Constitution similarly contains no provision for legal aid and does not even have an express due process clause. Yet on the broad language that "All Swiss are equal before the law," Swiss courts have spelled out a constitutional requirement that courts must grant comprehensive legal aid. See Jacoby, supra, at 942.

2. For an excellent historical treatment of the problems which confront needy litigants see Maguire, Poverty and Civil Litigation, $36 \mathrm{HARv}$. L. Rev. 361 (1923). For a comparable study of the growth of private legal aid facilities see MAGUInE, TrE LANCE of Justice (1928) ; SMith, Justice ANd the Poor (3d ed. 1924) ; Bradway, The Challchge to Organized Legal Aid, 22 Tex. L. Rev. 327 (1944); Cohn, The Political Partics and Legal Aid, 8 Mod. L. REv. 97, 108 (1945).

The seriousness of this problem is high-lighted by the inability of the layman to act as his own lawyer, for the complexities of modern life demand the services of a specially trained legal mind when legal relations come into contest. See EgERTON, LEGAl Aid 3 (1945); Legal Aid and the Legal Profession, 88 Sol. J. 301 (1944).

3. For British provisions see Report of the CoMnMittee on LeGAl Aid AND Legal AdVtce in England and Wales $\$ 66$, Cmd. 6641 (1945) (hereinafter cited as Repont). For analogous American provisions see note 43 infra. The expenses involved in a civil suit, apart from lawyer's compensation, may be broken down into court fees (charges for entering or docketing a case, service of process, filing subsequent papers, etc.), costs (sums 
ordinarily been available only in specified courts after an applicant has passed a stringent test of poverty, and thus have done little more than recognize symptomatic wheezes without diagnosing and treating basic ills. Needy persons confronted with the awesome prospect of civil litigation have seldom been provided with counsel, 4 and no thought has been given to the very real barrier posed by the out-of-pocket expenses incurred in preparing for trial.

To supplement the minimal governmental provisions, private groups of lawyers, financed by friendly members of the profession and public spirited laymen, have established legal aid and advice offices in some of the most populated areas. 5 These private institutions have assumed myriad organizational

payable to a successful opponent), and miscellaneous expenses (witness' fees, remuneration to expert witnesses, deposition expenses, etc.). See Mraguire, Legal Aid in 9 ENcyc. Soc. Scr. 319, 321 (1933).

4. Attempts to assign counsel in the absence of a statute specifically providing for this action have frequently been defeated by the argument that the Constitution guarantees that no man shall be compelled to render service or give up property vithout just compensation. Board of Commissioners v. Pollard, 153 Ind. 371, 375, 55 N.E. 87 (1899). Few American states have conferred a statutory power to assign counsel in civil cases. See, e.g., ARK. Stat. ANn. \$27-403 (1947); ILI. ANn. Stat. c. 33, \$ 5 (Supp. 1948); Irid. Stat. Ann. \$2-211 (Burns 1933); Kr. Rev. Stat. \$453.190 (1948); Mfo. Rev. Stat. ANN. \$1404 (1939) ; N.Y. Cw. Prac. ACt \$196; N.C. Gen. Stat. Ars. \$1-110 (1943); Tex. Stat. Rev. Crv. art. 1917 (1925); VA. Code ANn. $\$ 3517$ (1942); W. VA. Codz $\$ 5853$ (1943).

5. The existing British facilities are described in the REport $\$ \$ 83-123$. According to Elson there were in 1946 approximately 109 American organizations (legal aid societies, law school clinics, bar association committees, etc) serving a little more than $36,000,000$ people. See Elson, supra note 1, at 135. These facilities are constantly increasing. For example, the American Bar Association in 1946 authorized $\$ 10,000$ to be spent over a three year period for legal aid in Syracuse, Utiea, Binghamton, Fall River, Worcester, Atlantic City, Camden, Paterson, and Wilmington. These cities were chosen because they all had populations of over 100,000 persons. See The Bar Siorts a New Era of Practical Legal Aid, 32 A.B.A.J. 258 (1946). However, one cannot but remain concerned as to the success of these ventures, especially in light of the decrensing supply of private funds available for legal aid, see note 7 infro, and the success of the bar associations in having statutes passed prohibiting the "unsuthorized practice of law." See Bradway, The Challenge to Organized Legal Aid, 22 TEx, L. Rev. 327, 342-3 (1944); Sartir, Extending the Public Servtce of the Organized Bar traodgr Legar Am WORK (1943). For a general record of the activities of local and state bar associations in the field of legal aid, see BradWay, The Work of Legat Ato Cosonttees or Bar Assoctations (1938). Although a few legal aid bureaus are municipally supported and have salaried staffs, the vast majority are privately financed, and attorneys receive no compensation for the services which they render. Under the aegis of the National Association of Iegal Aid Organizations the quantity of aid provided by legal aid organizations has grown remarkably. See Annual Reports of N.A.L.A.O. Even so, in 1946 there were 25 cities of more than 100,000 which had no legal aid facilities at all.

It is doubtful that private legal aid as sponsored by the American Bar Association will ever be able to fulfill the need. Although an enthusiastic and forceiful legal aid committee has long endeavored to shake the Association into real action, it has been met with superficial approval, platitudinous praise, and little concrete support. Along with its plea for formal support of legal aid in 1938, the Legal Aid Committee stated: "The 
patterns, ${ }^{6}$ all designed to assist those unable to pay for legal services. Private funds, however, have been inadequate to meet the need, and virgin private

records, which we have studied, show that the one great objection [to legal aid] we must overcome is the following: A motion is made at a meeting that the bar association do something actively in behalf of legal aid work. That motion is then opposed by several honorable, splendid, capable members of the bar who state that they are glad to help poor persons in their own offices. That is true. But they have no conception of the full need and they do not, and can not, fill it. Even if they were to accept and act for every poor person that did apply for help, there would be a hundred times more of men, women, and children, that needed legal advice and assistance who had no idea where to go. In the larger cities, our experience convinces us, such persons do not know any competent lawyer who might be available and there is no way for them to find out. Our experience further convinces us that, in the larger communities, lawyers who are willing and who might be available have found that they are not equipped to handle any substantial number of the poor persons' cases and further that the nature of their practice has left them unskilled in many of the typical cases presented by the poor." iReport of the Legal Aid Committee, 63 A.B.A. REP. 273, 276-7 (1938).

The self-contented attitude of the American Bar Association is perhaps nowhere better illustrated than in the official report on the debate following the Legal Aid Committee's Report in 1940. It was said, "The debate [on legal aid] . . . was indicative of the intense interest manifested in the problem and of the desire of the members of the House to make certain that none shall be denied justice because of inability to pay a fee." 26 A.B.A.J. 108 (1940). Yet Harrison Tweed, Esq., reporting for the Legal Aid Committee, stated, "Today I am a little discouraged about the work of our Committec, and the attempt that we are making to secure justice for the poor throughout the country. The inertia and lack of interest on the part of the Bar are most pronounced." Id. at 829. In 1941 the Committee's request for $\$ 5000$ to carry on its work was denied. 27 Id. at 217 (1941). And in $1943 \mathrm{Mr}$. Tweed again complained that the Committee was in its "usual dilemma of trying to accomplish the impossible all at once." 29 Id. at 587-8 (1943).

6. Reginald Heber Smith, in his pioneering treatise, JUSTICE AND TUE Pook 169 (3d ed. 1924) classified American legal aid organizations into five types : private corporation societies, public bureaus, departments of organized charities, bar association socictics, and law school societies. Further classifications have been made by BRADWAY, LEGAL Am Bureaus: A Manual of Practice 9 (1935); Stewart \& Abrahams, Legal Aid it Civil Cases, 26 GEo. L.J. 32, 43 (1937). Organizational problems for smaller communities are discussed in Bradway, Forms of Legal Aid Organizations in Middle Sized Cities and Smaller Comanunities (1941).

An equally important role in supplying civil legal aid in America is played by municipal small claims courts which have been established in a number of cities to dispose of minor grievances. Costs in these courts have been reduced to a minimum by climinating fictitious charges, by permitting the parties to plead their own cases, and by using the most elementary procedure. Because of this informality, justice may be dispensed much more rapidly than in the ordinary courts. Court organizational schemes in many states, however, preclude the establishment of small claims courts because only a well organized and responsible municipal court can assume the additional burden implicit in the informal nature of these tribunals. Even where small claims courts may be established, their role in alleviating the need for legal aid is limited by their restricted jurisdiction. Sec Smith, Justice and tre Poor 41-59; Sutth \& Bradway, The Growth of Legal-Aid Work iN THE UNited States 34-45 (Dept. of Labor Bull. 607, 1936); Clark \& O'Connell, The Working of the Hartford Snall Clains Coutrt, 3 CoNs. B.J. 123 (1929); Jacoby, Legal Aid to the Poor, 53 HARv. L. REv. 940, 945 (1940); Pound, Administration of Justice in the Modern City, 26 HARv. L. REv. 302, 318 (1913). For a model bill 
sources daily diminish ${ }^{7}$ while the need for legal assistance steadily expands. Many parts of the country have no organized legal aid at all, and even where legal aid facilities are available they are provided only for those persons bordering on complete destitution. At best, only the most meager thought has been given to the needs of those millions who can afford to pay a part, but not all, of the costs of litigation.

establishing a small claims court, and for much valuable testimony pro and con on the merits of such a bill, see Hearings before Committec of the District of Columbia on S. 1835, 75th Cong., 1st Sess. (1937).

Also of importance are the procedures prescribed by workmen's compensation statutes. To administer these acts almost every state has established an industrial accident commission which handles all claims for disabilities arising in the course of employment. These commissions have a distinguished record for speed and accuracy, yet omit the customary fees and costs found in judicial proceedings. See Suntr \& BrnDway, Taz Growth of Legal-Am Work IN the United States 50-57 (Dept. of Labor Bull. 607, 1936). Some states have given further assistance by establishing labor commissioners to whom assignment of wage claims may be made for prosecution in cases where the $\mathrm{cm}$ ployee cannot afford to pay customary counsel fees. For a discussion and collection of these wage payment statutes, see id. at 64-6.

To a lesser extent domestic relations courts, arbitration provisions, and conciliation procedures have also done their bit to alleviate the demands which are put on formal legal aid. See id. at 46-9; SAmtr, Justice AND the Poos 73-82 (3d ed. 1924).

All of these institutional developments, from private legal aid and small claims courts to the meager conciliation provisions, represent efforts to deal with certain limited types or classes of cases. "Beyond them lies the whole area of legal litigation as to which no short cuts of procedural or administrative reform have been devised, where the need for the attorney's service remains as great as it has ever been, and where the only solution seems to be afforded by the further development and expansion of our legal-aid organizations." SAITH \& BRAdWAY, supra, at 33.

7. The seriousness of the problem is indicated by the words of Eustace Seligman, Esq., Treasurer of the New York Legal Aid Society, in a speech made to the New York State Bar Association. "We have done an inadequate job of providing legal aid in N $\mathrm{New}$ York City because our private charity sources are drying up. The change has already come. The problem is serious. . . . Realistically we cannot expect to get along without government money." N.Y. Herald Tribune, Jan. 28, 1949, p. 2, col. 6. The following is a breakdown of the contributions and income received by the New York Legal Aid Society during the year 1948.

LAw FIRMS :

26: ( $\$ 100$ per member; $\$ 10$ per associate) $\ldots \ldots \ldots \ldots \ldots \ldots \ldots \ldots \ldots \ldots \$ 47,370.00$

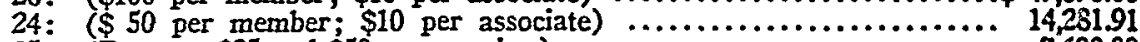

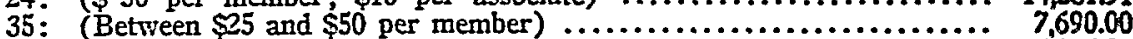

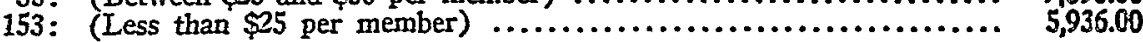

Total .....................................\$ $75,277.91$

1,396: Iawyers (individual) $\ldots \ldots \ldots \ldots \ldots \ldots \ldots \ldots \ldots \ldots \ldots \ldots \ldots \ldots . \ldots 17,178.20$

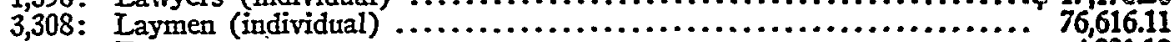

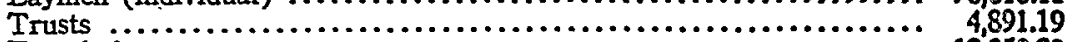

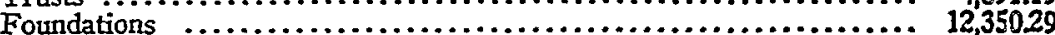

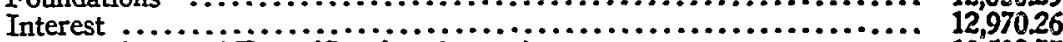

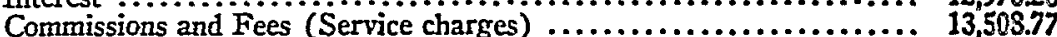

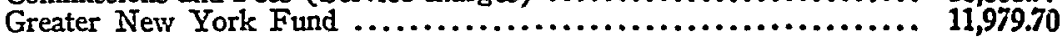

73D ANnuAl Report of the Legal Am Society (for the year 1948) p. 15.

$\$ 224,772.43$ 
The British Government recently determined that traditional public and private arrangements for providing legal assistance were wholly inadequate. ${ }^{8}$ In consequence, the Rushcliffe Committee was established to explore the problem and suggest reforms. The Committee's recommendations, which have been substantially embodied in the Legal Aid and Advice Bill of $1948,{ }^{10}$ take the position that legal aid in a democracy is not a matter of private or public charity but a right which the state has a duty to foster and protect.11 The Bill, which should take effect in 1950 , envisages legal assistance to all those now aided by in forma pauperis statutes and by private legal aid. In addition it provides legal services for those in the intermediary position of being able to pay only a portion of their legal expenses. In this sense, the Bill is an attempt to remove the vast discrepancy between the theory and practice of equal protection.

8. In England there has been no extensive development comparable to the American system of private legal aid. See notes 5 and 6 sipra. Where the statutory in forma pauperis failed to provide the necessary relief for a litigant he could turn only to Poor Man's Lawyer Organizations and Citizens' Advice Bureaus. See REPoRT \$33, pp. 17-22. These organizations in most instances provide only legal advice, and the English interpretation of the word "advice" is strict-it means oral advice coupled with an occasional letter, and nothing more. For a discussion of legal advice under the British Bill sec pp. 336-7.

9. The Committee of twenty experts was headed by Lord Rushcliffe, and is popularly referred to as the Rushcliffe Committee. Appointed by the coalition government in 1944, the Committee held 48 meetings, of which 26 were for the purpose of hearing evidence, before submitting its report in May 1945. RePoRT $\$ \$ 1,2$. Fifty-one witnesscs representing almost every interested segment of the population were examined and permitted to submit written evidence. REPORT, App. I, part 1. In addition, written evidence was received from 53 organizations and individuals whose names are listed in Part 2, Appendix I of the REPORT.

10. 12 Gko. 6, Bill 22 (hereinafter cited as BILL). The Bill passed its second reading in the House of Commons on Dec. 15, 1948, and was referred to a standing committee. See 459 H.C. DEB. 1228, 1333 (5th Ser. 1948). Sections 8 to 11 and section 13 of the Bill, dealing with the machinery of administration, came into force on Sept. 1, 1949. Communication to the Yale Law Journal from $H$. Ruth Isaacs, Reference Division, British Information Services, New York, dated Nov. 10, 1949, in Yale Law Library. The introduction of certain other parts of the legal aid scheme has been temporarily postponed. See address by Prime Minister Attlee as reported in British Information Services Release T. 80, Oct. 24, 1949.

Brief British explanations and comments on the Rushcliffe Report may be found in: Mullins, Legal Aid ad Infinitum-A Criticism of the Rushcliffe Report, 95 L.J. 215 (1945); Legal Aid and Advice-The Rushcliffe Committee's Report, 95 L.J. 192 (1945); The Rushcliffe Report, [1946] Scotr. L. TIMEs 25; The Report on Legal Aid, 89 SoL. J. 312,321 (1945).

11. REPoRT $\$ 125-7,140$; and see note 1 supra. See Cohn, Legal Aid for the Poor: A Study in Comparative Law and Legal Reform, 59 L.Q. Rev. 250, 251, 256 (1943). See also Jacoby, supra note 1, at 955 . Such a duty was long ago recognized in Austria. The Austrian Code of Civil Procedure (1895) expressly used the term armenrecht (the "poor man's right"), which was interpreted to mean that a poor person had a "right to demand that the State renders him legal aid free of charge-that it pays the outlays arising out of his litigation, and, if necessary, procures a gratuitous representation." Locwensohn, The Poor Man's Right to Legal Aid, 61 Scor. L. Rev. 55 (1945). 
The British plan contains techniques for solving a problem shared by Americans and English alike. It is in this light that the British Legal Aid and Advice Bill will be examined. ${ }^{12}$

\section{Financial Eligibility}

\section{EligtbILITy}

Two alternative tests have generally been employed to meet the problem of financial eligibility for legal aid. The first, a fixed means test, establishes prescribed income and wealth criteria. ${ }^{13}$ The second contemplates judicious exercise of discretion by those who determine eligibility. It permits aid to all who do not possess sufficient resources to pay the costs of the action in question, or who if they paid such costs would no longer be able to support themselves or their dependents. ${ }^{14}$ The Bill perpetuates the fixed means test of eligibility, but incorporates the Committee's recommendation of greatly liberalized

12. The British Bill contains a careful analysis of existing facilities for legal aid and advice in civil and criminal matters. The main thrust of the Bill, however, is in the field of civil litigation, since existing facilities for legal aid in criminal matters are adequate. Similarly, this Comment will be concerned only with the civil aspect of legal aid and advice.

13. For the historical development of the fixed means tests in England see Mraguire, Poverty and Civil Litigation, 36 HARv. L. REv. 361 (1923). This notion of a rigid means standard, which must be complied with if legal assistance is to be given, is followed in only a few places, largely in the Anglo-American countries. See Egerro:r, LegnL Ald 51 (1945) ; Cohn, Legal Aid for the Poor: A Study in Conparatize Lazu and Legal Reform, 59 L.Q. REv. 250, 271 (1943).

According to a study made by the National Association of Iegal Aid Organizations in 1936, however, in forna pauperis statutes in 41 of the American states had no fixed means test. See EgERTon, Legar Am 71 (1945). But before an applicant may receive the assistance contemplated by the in forma panperis statute in question, he must still convince the court of his financial need. See statutes cited in note 4 sispo. New Yorl, using the fixed means test, prescribes a limit of $\$ 300$. N.Y. CIV. PrAc. Acr $\$ 199$. And Arkansas carries the fixed means test to the absurd extreme of requiring a petition stating that the applicant is not worth more than $\$ 10.00$ over and above wearing apparel necessary for himself and his family. The subject matter of the action is not included in the computation, however. ARK. Stat. Awr. \$27.402 (1947). The Ameriean Bar Association also apparently endorses the fixed means test. See Draft of a Mrodel In Formo Pauscris Statute, reprinted in Sarith \& Bradway, The Growtr of Legal-Aw Wonk ri the UNITED States 175-80 (Dept. of Labor Bull. 607, 1936).

14. This flexible standard is the customary test in most countries. See, c.g., Legar Am FOR THE POOR (League of Nations Publications V: Legal No. 27) (1927) (hereinafter cited as League of Nations Report); Egerton, Legal Ato 51, 71 (1945). And see Jacoby, Legal Aid to the Poor, 53 HARv. L. Rev. 940, 958-61 (1940), for a diseussion of the flexible standard under the German, Austrian, French, Czechosloval;, and Hungarian systems. The Hungarian statute provides, "Legal aid may, as a rule, be granted to a person whose income does not exceed the current day-labourer's wage in his place of residence. The court may, however, after taking all circumstances into account, similarly grant legal aid to a person who is unable to bear the cost of legal proceedings without encroaching on the resources necessary for his maintenance or the maintenance of those members of his family for whom he is required either by statute or common law to make provision." (Translated and reprinted in League of Nations Report 108-9). 
wealth and income criteria. ${ }^{15}$ Legal aid will now be available to any person whose disposable income and capital does not exceed $£ 420$ ( $\$ 1176)$ and $£ 500$ $(\$ 1400)$ respectively.

Since poverty itself is a relative concept, any fixed means test, no matter how liberal, seems inappropriate. ${ }^{16}$ Five hundred dollars in the pocket of an expectant father is not equal to five hundred dollars held by his less prodtuctive fellow. Such varying circumstances can be handled by leaving eligibility to the determining authority's discretion, as most American statutes do.17 The application of a general definition of poverty to the facts of $a_{4}$ particular case has never caused difficulty, and the mere lack of fixed limits does not of itself result in increased litigation. ${ }^{18}$

A far more important aspect of the Bill, however, is that it makes legal services available to those who can only partially meet the costs of litigation. ${ }^{10}$ Frank recognition of this problem prompted the draftsmen of the Bill to eliminate the concept of "paupers" and speak in terms of "assisted persons." The Committee recommended completely free assistance where an applicant's disposable capital is less than $£ 25(\$ 70)$ in the case of a single person, and f50 (\$140) in the case of a married man. ${ }^{21}$ The Government considered these sums to be ungenerous, however, and raised them to $E_{75}$ (\$210) and $£ 150$ (\$420) respectively. ${ }^{22}$ Those whose disposable income and capital are more than the fixed upper criteria set forth in the Bill are still eligible for assistance, but they must contribute from their resources until these resources fall to the level of their statutory exemption. ${ }^{23}$

15. REPORT \$156(7); Bill cl. 3(1). LEgAL Aid AND Advice Bill of 1948-SUMasary of the Proposed New Service 6, Cmd. 7563 (1948) (hereinafter cited as SumMARY).

16. Thus Italy and Egypt have specifically defined poverty, so far as legal assistance is concerned, to mean only a condition which renders the applicant incapable of bearing the costs of the litigation. It is expressly stated that poverty does not, for this purpose, mean complete destitution. See League of Nations Report 120, 174. Dr. Cohn cmphasizes the relativity of "poverty" and concludes "all that can be demanded of a modern legislator is that he leaves this question to the discretion of the authority which has been granted jurisdiction to decide it." Cohn, Legal Aid for the Poor: A Study in Comparative Law and Legal Reform, 59 L.Q. REv. 359, 360 (1943).

17. See statutes cited in note 31 infra; note 13 supra.

18. See Egerton, Legal Aid 71 (1945); Cohn, Legal Aid for the Poor: A Study in Comparative Law and Legal Reform, 59 L.Q. REv. 359, 360-1 (1943).

19. BrLL cl. 2-4.

20. See REPORT $\$ 127(9)$ and BrLL cl. 3.

21. REPORT $\$ 156(7)$.

22. Bill cl. 3(1) ; Summary p. 6.

23. In qualifying for assistance under the Committee's proposal two separate criteriadisposable capital and adjusted income-must be kept in mind. An applicant's capilal exceeding $£ 25$ ( $\$ 70)$, if single, and $£ 50$ (\$140), if married, is available for contributions. These figures represent disposable capital, however, and need further explanation. In calculating disposable capital the capital of husband and wife are normally aggregated; but household effects, tools of trade, the applicant's house, and capital employed in a 
Compared to the program envisaged in the British Bill, American facilities for providing legal services to those only partially able to meet litigation expenses are but a shadow. Four rather faltering steps have been taken by American bar associations to assist this group of litigants :24 central offices equipped with reference lists of qualified lawyers willing to undertake small cases at moderate fees; $;$ the neighborhood law office plan, which contemplates the establishment by existing law firms of small offices in residential areas,;6 "legal service bureaus" staffed by salaried lawyers specializing in work at cost for the low income groups; $; 7$ and finally, various proposals for reducing high overhead costs..8 Unfortunately, these facilities are available

business (if its inclusion would diminish an already small or uncertain income) are omitted. REPORT $\$ 156(7)$. In addition, one-half the difference between an applicant's adjusted income (i.e., gross income less designated deductions) and the statutory level below which aid is free ( $£ 156(\$ 436.80)$ for a single person, $£ 20 \$$ (\$582.40) for married persons) is available for contributions to the Legal Aid Fund. REPORT \$156(1). In computing this adjusted income, the income of both husband and wife are normally to be aggregated, but this is not true about any other member of the family. REPORT $\$ 156(2)$. All those whose disposable income is more than $£ 420$ ( $\$ 1176$ ) are not eligible for aid. (With the exception of the increased amounts provided for disposable capital, the Bill adopts these provisions in toto. BIII cl. 2-4.)

Determination of financial eligibility is the only part of the proposed plan that the Law Society (see note 74 infra) refused to administer. See Lund, The Legal Ald and Advice Scheme, 4 Recond N.Y. CITY B.A. 77, 81 (1949). The Committee therefore recommended that the National Assistance Board (which is somewhat similar to American unemployment compensation commissions) make this determination. REPORT \$156(11). There is no appeal from the determination of the Assistance Board. Ibid.

24. See Smith, Legal Service Offices for Persons of Moderate MIcans, 31 J. Axs. Jud. Soc'y 37 (1947).

25. There are indications that in recent years bar associations have finally come to realize the good will which these reference plans bring to the legal profession. This probably has been as strong a factor as any other in the increased interest in extending the reference facilities. For detailed discussion of reference services see Fisher, Laiuyer Rcference Plan in Operation, 21 CHI. BAR Rec. 136 (1940); Hanna, Pliladelplia Adopts the Lawoyer Reference Plan, 20 PENN. B.A.Q. 44 (1948); Lafferty, Philadclphia's Law Reference Service, 22 TExs, L.Q. 195 (1949). For the attitudes of the American Bar Association, see Report of the Committce on Legal Sercice Burcaus, 65 A.B.A. Rer. 255 (1940) ; for views of local bar associations see 66 id. at 329-30 (1941); and see Rcport of the Committee on Legal Service Burcaus, 66 id. 321 (1941); 67 id. at 290 (1942).

26. See Egerton, Legal AId 117 (1945); Garrison, Legal Scrice for Low Income Groups in Sueden, 26 A.B.A.J. 215 (1940). Bar associations are to supervise this service.

If neighborhood law offices are to perform a useful service it is generally thought that they must be widely publicized and must be open in the evenings so that clients will be able to take advantage of their facilities without having to miss vital working time. See The Econonsics of the Legal Profession (findings of a Connecticut survey under the auspices of the Yale Law School) 148-52 (1938).

27. See Bradway, Low Cost Legal Serzice Burcats, 17 N.C.L. Rev. 101, 103, 107 (1938) ; Llewellyn, The Bar's Troubles, and Poultices-and Cures?, 5 LAw \& Co:Tearr. Prob. 104, 113, 121-30 (1938) ; Llewellyn, Legal Sercice Bureats, 19 Car. Bas Rec. 95, 125 (1938).

28. But the nature of legal work is not conducive to the elimination of overitead expenses. See The Econoxics of the Legal Professiox, supra note 26, at 88-97. 
in only a few places. Integration with existing legal aid bureaus would seem the most logical method of extending this service. The American Bar Association, however, has opposed such action for the somewhat vague reason that confusion would result between the two services, one based on charity and the other on limited compensation. ${ }^{29}$

\section{Legal Eligibility}

Once an applicant for legal aid has established his financial eligibility under the British plan, two further problems remain. Opponents of assisted parties must be protected from needless proceedings, and useless expenditures of funds must be prevented. Therefore, an applicant must justify his request for assistance. This has previously been handled in three ways : either the applicant may be required to establish a prima facie case (or at least show probable cause) $;^{30}$ or the matter may be left entirely within the trial judge's discretion, as in most American states having statutory provisions for legal aid ;1 or the action must be permitted unless it is apparently ill founded. ${ }^{32}$ The Bill in effect has continued the existing English practice which requires the establishment of a prima facie case. ${ }^{33}$ The provision is sound. Those who can afford to litigate will ordinarily refrain from so doing in the absence of $\mathfrak{a}$ prima facie case. Requiring assisted persons to establish a prima facie case would simply place them on the same footing with other litigants.

29. Report of the Committee on Loze Cost Legal Service Bureaus, 67 A.B.A. Rew. 290,291 (1942).

30. A rule requiring the establishment of a prima facie case is by far the most common of all criteria. See, e.g. England, 11 HeN. 7, c. 12; 23 HEN. 8, c. 15, §2; Brazil, League of Nations Report 68; Denmark, $i d$. at 115; France, $i d$. at 131 ; Norway, id. at 202. For an interesting international comparison see Cohn, Legal Aid for the Poor: $A$ Study in Comparative Law and Legal Reform, 59 L.Q. REv. 359, 362 (1943).

31. See, e.g., Ark. Stat. Ans. \$27-403 (1947); Colo. Stat. Ann. c. 43, \$22 (Supp. 1947) ; Ill. AnN. Stat. c. 33, § 5 (Supp. 1948); Ind. Stat. ANN. \$2-211 (Burns 1933); Ky. Rev. Stat. $\$ 453.190$ (1948); Mrсn. Stat. ANo. $\$ 27.738$ (Henderson 1936); Mo. Rev. Stat. Ann. $\$ 1404$ (1939); W. VA. Code $\$ 5853$ (1943). Cf. Flu. Stat. Ann. $\S 58.09$ (1943) (requiring a written certificate from a member of the county bar association that he has investigated the plaintiff's affidavit of indigency and believes it to be true, and has investigated the nature of the plaintiff's claim or demand and belicves that it is meritorious as a matter of law, and that he has not been paid or promised any fee or other remuneration for his service and intends to act as attorney for the plaintiff without compensation); Wash. Rev. Stat. ANs. \$10007-208 (1940) (requiring the bar association to determine the eligibility of applicants-see note 87 infra).

32. See, e.g., Belgium, League of NATions Report 51; Germany, id. at 135; Poland, id. at 206. Two countries go even further than this. Finland and Sweden do not even require that good cause be shown. See Cohn, Legal Aid for the Poor: A Study in Comparative Law and Legal Reform, 59 L.Q. REv. 359, 362 (1943).

33. BILl cl. 1 (6) ; and see REPorT § 141. It is interesting that the Bill does not adopt the language "prima facie" as employed in the Report. The Bill rather says, "A person shall not be given legal aid in connection with any proceedings unless he shows that he has reasonable grounds for taking, defending or being a party thereto, and may also be refused legal aid if it appears unreasonable that he should receive it in the particular cir- 
Unlike many American statutes which arbitrarily restrict their benefits to residents or plaintiffs, ${ }^{34}$ the Bill aids all-plaintiff or defendant, citizen or alien-who qualify. ${ }^{35}$ In addition, the Committee recommended that aid be available in all types of proceedings except county court judgment summonses or proceedings by defendants where only time and mode of payment of debt are in issue. ${ }^{36}$ The actual provisions of the Bill are more limited, however, for they exclude, in addition to the above named proceedings, actions for libel and slander, breach of promise of marriage, actions by common informers, and certain others. ${ }^{37}$ This list is not inflexible, and may be increased or decreased in the light of experience. ${ }^{38}$

cumstances of the case." Bris cl. 1 (6). It may be that the draftsmen of the Bill purposely avoided the use of "prima facie" in a deliberate attempt to obviate academic arguments concerning the definition of the term. By using lay language and talking in terms of "reasonable grounds" it may be simpler to apply the test of legal eligibility suggested by Dr. Cohn-i.e. that assistance should be granted if a private attorney could, with a clear conscience, advise the client to assume the risk of litigation. See Cohn, Lcgal Aid for the Poor: A Study in Comparative Law and Legal Reform, 59 L.Q. Rev. 359, 363 (1943).

34. Certain American statutes restrict their benefits to residents of the state E.g., Ariz. Code Ann. \$21-602 (1939); Kan. Gen. Stat. ANw. §60-2401 (1935); La. Geri. STAT. ANN. $\$ 1400$ (1939) (only residents or aliens who have been domiciled three years in the state eligible); Mircr. Stat. ANw. $\$ 27.738$ (Henderson, 1936). And others restrict their benefits to plaintiffs. See, e.g., ArIz. Conघ ANw. \$21-603 (1939); Kurs. GErs. Stat. ANN. §60-2401 (1935); Mrter. Stat. ANw. §27.738 (Henderson, 1936); Mlo:it. Rev. Codes Anv. §9809 (1935); N.C. Gen. Stat. AnN. §1-110 (1943); Orfu. Stat. ANN. tit. 12, \$921 (1938).

35. The Bill provides that "legal aid shall be available for any person whose disposable income does not exceed four hundred and twenty pounds a year: provided that a person may be refused legal aid if he has a disposable capital of more than five hundred pounds and it appears that he can afford to proceed without legal aid." Brut cl. 2 (1) (italies added).

36. REPORT $\$ 165$.

37. BII, 1st Schedule, Part II. In addition to the specified actions, the following proceedings are also excluded: loss of the services of a woman or sirl in consequence of her rape or seduction, the inducement of one spouse to leave or remain apart from the other, relator actions, election petitions under the Parliamentary Elections Act (1868) or the Mrunicipal Corporations Act (1882), or proceedings incidental to any of these actions.

38. See BrL cl. 1 (3), (4).

Contrast the report of the New York Legal Aid Society for 1948, showing the nature and number of its cases:

IV-DATA AS TO NATURE OF CASE:

1. Econosir:

a. Growing out of contract: Wages $\ldots \ldots \ldots \ldots \ldots \ldots 1,187$

Work, labor and service .... 259

Promissory note ........... 122

Small loan, private .......... 157

Small loan, Public Co. ...... 127

Other money claim ........ 702

Installment contract ........ 231

Wage assignment-garmishee 111
Insurance $. . . \ldots \ldots \ldots \ldots \ldots, 299$

Partnership ................ 114

Breach of Contract ........ 1,740

b. Torts:

5,049

Personal Injury .......... 838

Attorney and Client ......... 144

Libel and Slander ........... 91

Fraud .................... 26

Other Torts .............. 770

1,869 
Significantly, the Rushcliffe Committee recommended that legal aid be extended from the few courts where it is now available to all courts and tri-

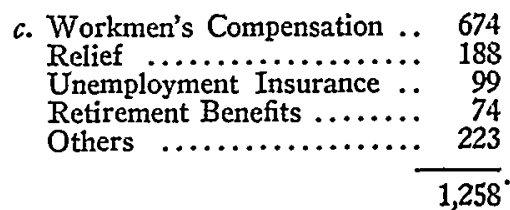

2. FAMILY:

a. Husband and Wife:

Domestic Difficulty ...... 2,340

Annulment ............ 882

Divorce .............. 2,772

Separation $\ldots \ldots \ldots \ldots \ldots \ldots, 1,184$

Support $\ldots \ldots \ldots \ldots \ldots \ldots \ldots 1,111$

Alimony $\ldots \ldots \ldots \ldots \ldots \ldots \ldots, 261$

Dissolution ............. 264

8,814

b. Parent and Child:

Adoption ............. 428

Support ............... 325

Custody $\ldots \ldots \ldots \ldots \ldots \ldots \ldots .510$

Guardianship ........... 61

Illegitimacy $\ldots \ldots \ldots \ldots \ldots \ldots .6 .194$

1,518

3. Property:

a. Real Estate:

Landlord and Tenant ....... 3,508

Personal Property ........ 604

Investments ........... 105

4,217

b. Estates :

Of deceased $\ldots \ldots \ldots \ldots \ldots .989$

Of insane $\ldots \ldots \ldots \ldots \ldots \ldots \ldots .174$

Of feebleminded .......... 58

Of minor $\ldots \ldots \ldots \ldots \ldots \ldots \ldots, 286$

Of bankrupt ........... 41

1,548
4. Other:

Miscellancous ............ 9,804*

Patents .............. 68

Drafting legal doctuments ... 326

Change of Name .......... 280

10,478
V-SERVICE RENDERED:

1. Consultation only: Advice given

2. Consultation and referral:

To Government Agency . . . . 1,003

To Social Agency ......... 693

To Private Attorney ....... 1,717

To Special Court ........... 1,790

3. Service completed without

Court Action:

Investigated and advised . . 1,355

Documents drawn .......... 390

Partial Settlement ......... 38

Satisfactorily settled ....... 942

4. Closed after Court Action:

Case Completed:

Won $\ldots \ldots \ldots \ldots \ldots \ldots \ldots \ldots .142$

Lost $\ldots \ldots \ldots \ldots \ldots \ldots \ldots \ldots \ldots . . \ldots \ldots$

Settled ............... 56

Discontinued ............ 18

Exparte Applications ...... 352

5. Terminated after partial

service:

Withdrawn ............ 328

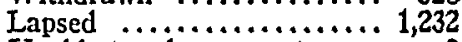

Unable to advance costs .... 0

" "Miscellaneous"-represents any legal problem not presently classified by the National Aa. sociation of Legal Aid Organizations, whose case titles and categories we follow. Miscellancouts may include such matters as problems in connection with service men absent without leave; Immigration; questions regarding Estate Income or personal Income Tax; attempting to locate relatives; or de. termination of date and place of birth, among others.

73d Annual Report of the New York Legal Aid Society (for the year 1948).

The wide scope of these cases would seem to indicate that private legal aid organizations in America have not been concerned with the problem of refusing particular cases because of the nature of the cause of action. In America the cause of rejection has more frequently been that the case is one which a private attorney would handle on a contingent fee. The contingent fee has never been a serious problem in England, for taking such a case is there regarded as a breach of professional ethics. See Gurnex-CunMrion, JUSTICE AND THE POOR IN ENGLAND 80 (1926). Although contingent fees are still frequent in the United States, they have long been condemned as a method of unfairly exploiting clicnts. See Choate, American Addresses 308 (1911) ; Report of the Jotnt Committee for tue StUdy of Legal AID 106 (1928). 
bunals in which counsel normally appear..$^{30}$ While the Bill extends legal aid privileges to litigants appearing in virtually all courts, the Government decided that inclusion at the outset of administrative tribunals was too vast an undertaking. ${ }^{40}$ In those tribunals which are covered, however, the Bill explicitly provides for appeals, ${ }^{41}$ which are often denied in this country in the absence of express statutory authorization. ${ }^{22}$

\section{Extent of Ain to Assisten Persons}

\section{Finnancial Assistance}

The Bill represents a sharp departure from traditional American and British thinking on the issue of costs. Only a minority of our states assist needy litigants with court fees and costs, ${ }^{43}$ and instances of assistance with out-of-

39. At present legal aid is available in England only in the Supreme Courts. It is in the lower, or county courts, however, where a poor litigant is most likely to need legal assistance. Yet no system has ever existed for the assistance of poor persons there. Sce REPORT $\$ 32$.

40. Brr, 1st Schedule, Part I. Although the Bill did not adopt the Committee's complete recommendation, provision is made to extend the available tribunals if circumstances warrant such action. BILI cl. 1 (3), (4).

41. There is to be no interlocutory appeal without the consent of the Area Committer, and a fresh certificate permitting legal aid must be granted before any appeal other than an interlocutory one may be taken, REPORT $\$ 171$ (21), (22).

42. See Comment, 4 So. CaIIF. L. Rev. 295 (1931). Examples of statutes which malie specific provision for appeals in forma panperis are: GA. CODE ANN. $\$ 6-61002$ (1936); Kan. Gen. Stat. AnN. \$61-1002 (1935); LA. Gen. Stat. Axis. \$1400 (1939); Mircr. Stat. And. \$27.2613 (Henderson 1936); Mirss. Code ANn. \$1175 (1942); PA. Stat. Ann. tit. $5 \$ 72$ (1930); Tex. Stat. Rev. Crv. art. 3701 (1925); Wis. Stat. \$274.16 (1947).

43. See Report $\S 66$.

In America some states give assistance only in the matter of court fees. E.g., Ans. STAT. ANN. \$27-404 (1947) (complete exemption from court fees for those qualifying for aid). Other states give assistance only in the matter of costs, by waiving the necessity of a bond or other security. See, e.g., Arrz. Code ANs. \$21-602 (1939); KAri. GEri. Stat. Ann. \$60-2401 (1935); Mrcr. Stat. ANn. \$27.73S (Henderson, 1936); ORLA. Stat. ANn. tit. 12, 921 (1938); Wis. StaT. $\$ 307.08$ (1947). A greater number of statutes give assistance in both costs and fees. See, e.g., Colo. Star. Akz. c. 43, $\$ 22$ (Supp. 1947) ; Ill. ANn. Star. c. 33, \$ 5 (Supp. 1948) ; INd. Star. Amr. \$2-211 (Burns 1933); Ky. Rev. Stat. $\$ 453.190$ (1948) ; LA. Gen. Stat. ANr. $§ \S 1402-3$ (1939); Mo. Rev. Stat. ANN. $\$ \$ 1404-5$ (1939) (if costs recovered, court fees are given a first lien on the recovery); Monr. Rev. Cones ANr. $\$ 9809$ (1935); N.Y. Crv. Prac. ACt $\$ 1493$ (if the assisted litigant loses, no costs are recoverable asainst him; but if he is successful he may recover costs which are paid to his attorney after the county which advanced his costs has been reimbursed for its expenditure); TEx. Stat. REv. Crv. art. 2051 (1925); VA. CODE ANN. $\$ 35.17$ (Supp. 1948) (counsel and court officers not to be reimbursed except from costs which are recovered); W. VA. Cone $\$ \$ 853$ (1943) (vitnesses, in addition to counsel and court officers, may be reimbursed if the costs recovered are sufficient).

The system of costs which exists in the United States and Great Britain has developed most irrationally, largely due to unthinking statutory preservation of historical hangover. 
pocket expenses are rare indeed. ${ }^{44}$ When assistance is given, it is of a negative sort in that court costs simply are not assessed. In England under existing in forma pauperis provisions a litigant receiving legal aid is exempted from court fees and ordinarily does not have to pay costs to his own or his opponent's solicitor. But he must make an advance deposit of $£ 5$ ( $\$ 14$ ) to meet out-of-pocket expenses such as witness' fees, fares, and telephone calls. ${ }^{40}$ This requirement frequently defeats litigation before it can begin. Moreover, a poor person who successfully maintains an action may not recover costs from his opponent beyond the amount which he himself has paid to meet these out-of-pocket expenses, ${ }^{46}$ a provision which makes assistance most unattractive to his attorney.

The new British Bill comprises the first complete and integrated attempt to deal with the entire problem of costs. ${ }^{47}$ It provides that an assisted litigant

Court costs are a survival of old practices that arose when the administration of justice was regarded as a source of revenue to the crown. Willoughry, Principles of Judicial AdArinistration 572 (1929). Any argument based on the theory that government needs the minute additional income derived from court costs is evidently absurd. Noreover, it has been pointed out that there has never been any scientific principle in applying the doctrine of costs. Thus infinite variations have resulted and the actual costs in a particular suit bear little relation to the nature of the suit either from the state's or litigant's point of view. See SMItr, Justice AND the Poor 20-30 (3d ed. 1924). The author writes: "The bill of costs includes $\$ 1$ for a writ that can be purchased at any law stationers for $\mathbf{5}$ cents. It allows to the prevailing party two or three dollars as an attorncy's fee, while the actual charge made by the attorney to his client is probably ten times that amount. The fees paid by the litigants bear no closer relation to the state's expense in maintaining the judicial organization. ... If the existing system were brought forward de novo it would be ridiculed as absurd." Id. at 23. See, further, Smith, Dettial of Jilstice, 3 J. Ax. Jud. Soc'y 112, 115 (1919). For an historical treatment of the problem of costs which takes issue with the views expressed by Mr. Smith, see Goodhart, Costs, 38 YALE L.J. 849 (1929).

44. See note 45 infra.

45. REPORT §67. American statutes, with few exceptions, have similarly neglected to provide any assistance in this sphere. Louisiana, however, does specifically prohibit court stenographers, public officers in charge of records, notaries, and others from charging any fees to an assisted litigant, unless these fees are made contingent upon the amount recovered in the litigation. La. Gen. Stat. Ann. $\$ 1400$ (Dart, 1939). New York permits assisted litigants to submit typewritten records on appeal, thus saving printing costs. N.Y. CIv. PRAC. Acr $\$ 558$ (Clevenger, 1949). West Virginia makes an assisted litigant liable for witness fees only if his recovery is sufficient to meet these charges. W. VA. CODE $\$ 5853$ (1943). And the Third and Fourth Circuits have adopted rules pursuant to Rule 75(o) of the Federal Rules of Civil Procedure permitting appeals to be heard on the original trial papers. See 32 J. Ax. JuD. Soc'Y 118 (1949); id. at 155.

46. Report $\$ 68$. For analagous American provisions see sources cited in note 43 supra.

47. REPORT $\S \S 181,182$. The Rushcliffe Committee rejected the traditional vicw under in forma panperis statutes that court costs should not be assessed when an applicant qualifies for assistance. In its place the Committee adopted the view that the assisted litigant and the Fund should share in meeting the full costs. The Committee stated, "[assisted litigants] should be in all respects placed in the same position as those who are able fully to pay the costs involved. ... This will involve no additional expense upon the Exchequer for it will pay with one hand and receive with the other." Ibid. 
will be entitled to recover costs against an unassisted litigant as if both were parties to a privately financed lawsuit. 48 The costs recovered are paid in to the Legal Aid Fund. ${ }^{49}$ If, however, the assisted person's account with the Fund indicates a deficit, any money or property recovered is used to help balance his account. ${ }^{50}$

If an assisted person is unsuccessful, the bill provides that liability for his own costs is limited to the amount of his contribution, if any. ${ }^{51} \mathrm{He}$ will, moreover, be liable for his opponent's costs only to the extent the court believes reasonable in the light of his financial circumstances. ${ }^{52}$ But no reason appears for foreclosing the right of the opponent eventually to collect costs. Slight likelihood of collectibility may exist, but to deny this right is tantamount to saying that no money judgment should be given against an unsuccessful assisted defendant merely because the judgment cannot be satisfied at the time. ${ }^{54}$ It would, of course, be equally harsh to require an unsuccessful assisted person to lose his household furnishings and small savings because he failed in a case which was considered reasonable for him to bring or defend. But both considerations could be taken care of by allowing a decree for full costs which could not be enforced until the assisted litigant was able to pay.

48. BIIL cl. 1(7) (b) and RePORT \$ 173 .

Two theories have conventionally been advanced to deny any liability for costs on the part of an assisted person's unassisted opponent. The first is that liability for costs is the result of an obligation to indemnify the successful litigant, and if the assisted person is unable to pay his costs, he suffered no loss for which he could be indemnified. The second theory is that since the opponent could not recover costs in the event of his suceess, it is only fair that he be relieved of any obligation to pay costs in the event he fails in the litigation. But these arguments ignore many of the practical aspects of litigation. For instance, the first theory would prevent the liability of an unassisted opponent for costs which he would ordinarily have to pay in cases where lawyers represent charitable organizations without reward. The second theory benefits the wrong people. "It cxcuses the 97 per cent. of poor persons' opponents who would normally have to pay costs and it does not help the 3 per cent. who would normally have their costs paid; it penalizes conducting solicitors and the Treasury in 97 per cent of the cases and it doesn't help them in the remaining 3 per cent." EGERTON, LEGAL AID 82 (1945). See also note 53 infro.

49. BIIr cl. 3 (3); Sunarary \$25.

Money already contributed by the assisted litigant to the Fund is returned.

50. BIIL cl. 3 (4); SuMNALARY $\$ 25$.

51. BIrL cl. 2 (2) (e); SuArarary \$26.

52. BIIL cl. 2 (2); SUNATARY $\$ 26$.

53. It has been recognized in other countries that the obligations between litigants do not become altered merely because one of them has had the benefit of free legal assistance. See, e.g., Germany, League of Nations Report 136; Sweden, id. at 232, 235; Switzerland, id. at 270. It has been suggested that the section of the Bill dealing with the assisted party's opponent was not given sufficient thought. Cohn, Political Parties asd Legal Aid, S MOD. I. REv. 97, 116 (1945). And if the object of the Bill is to put all litigants in an equal position, it would seem that the Bill should not tip the scales in favor of the poor person at the expense of his wealthier opponent. See Cohn, Legal Aid for the Poor: $A$ Study in Comparative Law and Legal Reform, 59 L.Q. REv. 359, 373-4 (1943) ; EGEnTo:, LEGAL AID 83 (1945).

54. See Cohn, Legal Aid for the Poor: A Study in Comparative Law and Legal Reform, 59 L.Q. Rev. 359, 374 (1943). 
Answering another financial problem, the Bill provides the attorney with sufficient funds to meet out-of-pocket expenses. These advances may be obtained from the Area Committee ${ }^{55}$ by submitting details of the amount required and the reasons for the expenditure. ${ }^{58}$ As a check on excessive spending, however, the Area Committee is given power to question, refuse, or modify any proposed expenditure. ${ }^{57}$

\section{Provision for Counsel}

Anglo-American statutory measures dealing with the assignment of counsel in civil cases are rare and most inadequate. ${ }^{58}$ In those few instances where counsel is assigned, it is done arbitrarily, with no consideration of the assisted litigant's personal desires. ${ }^{52}$ This mechanistic procedure does injury to an attorney-client relationship based on intimate confidence and trust, which can best be guaranteed if counsel is voluntarily selected by the litigant himself. The Bill accepts this principle. Members of the legal profession are yot forced to participate in this plan-only those who volunteer are placed on panels. And the assisted party may choose whichever attorney he wishes from a list of those who have volunteered to participate in the program. ${ }^{00}$

55. For a discussion of the Area Committees see p. 338 infra.

56. REPORT $§ 171(17)$.

57. Ibid. Thus, before any expense may be incurred for an expert witness, the solicitor must obtain the permission of the Area Committee. REPORT $\$ 171$ (19).

58. A representative list of those American states which provide for assignment of counsel in civil cases may be found in note 4 supra. Even if all states provided for as signment of counsel, the operation of the system under our present in forma pauperis statutes would probably be a failure, because inadequate provision is made to reimburse attorneys for their services. See Smite \& Bradway, The Growtra of Legal-Aid Work in teE UNITED States 28-30 (Dept. of Labor Bull. 607, 1936). For an indication of the inadequate provisions for paying assigned counsel even in criminal matters see note 64 infra.

59. In the United States the selection of a lawyer for one receiving the benefits of an in forma pauperis statute is usually done by the court, see note 4 stipra, on the theory that the lawyer is an officer of the court and it is his duty to give free help to those in need. See Smith \& Bradivay, The Growtr of Legal-Aid Work in the United States 27-8 (Dept. of Labor Bull. 607, 1936). Some foreign countries have likewise permitted the judge to select the attorney. See, e.g., Denmark, League of Nations Reront 115; Norway, id. at 202. In other countries, however, some professional body has made the sclection. Sec, e.g., Austria, id. at 36; and Czechoslovakia, id. at 110.

60. BILL ci. 5 (3). The Rushcliffe Report outlines in considerable detail the panels which are to be established and makes it clear that once a client has been accepted for legal aid he may choose his lawyer from all those who are on the pertinent panel. Reront $\S 171(12)-(16)$. These provisions were adopted in the Bill. See BILL cl. 5 (3). This freedom of selection on the part of the assisted litigant will be of real value, for current indications are that virtually all lawyers will participate in the program.

The Bill also provides that a solicitor on a panel may not refuse to accept a qualified client unless he is already retained by or regularly acts for another party to the litigation, or he has so much business that it is impossible for him to undertake more, or unless thero are personal reasons-e.g., because of something that has happened in the past, the solicitor has told the client that he would not act for him. REPORT $\$ 171$ (15). For the view of The Law Society (see note 74 infra) on this matter see Lund, The Legal Aid and Advice 
Moreover, there are a number of panels covering various types of legal problems, so that a lawyer who does volunteer may specify the nature of cases which he is willing to handle. ${ }^{01}$

The Bill provides for compensation to lawyers who participate in the plan.62. This should benefit lawyers and assisted litigants alike. A full scale legal aid program will involve countless hours of work for innumerable attorneys. Poverty is not a condition for which lawyers are uniquely responsible, and they cannot and should not be expected to make adequate legal services available gratuitously to all who, because of their poverty, are unable to pay for litigation. ${ }^{63}$ And compensation will also benefit the litigants, for if lawyers are paid they will undoubtedly devote more time in preparing their legal aid cases. American states have not yet recognized these principles, and still require that legal services be donated in civil cases.ot

Schente, 4 RECORD N.Y. CITY B.A. 77, 84-6 (1949). Preservation of the client's right to select his lawyer has been acclaimed in England as being of the greatest value to both the client and lawyer. See Cohn, Legal Aid to the Poor and the Rusheliffe Rctort, 9 Mrop. L. REv. 58 (1946).

61. Members of the Bar will not be compelled to participate in the program. Those who do may place their names on any panel and upon any number of panels. Barristers and solicitors may resign at any time after they have completed matters on hand. The panels which are contemplated are:
a. Advice
b. High Court and Appeals for divorce business.
c. High Court and Appeals for all other civil litigation.
d. County Courts, Coroners' Courts, and Special Tribunals.
e. London agency business.

REPORT $\$ 171$ (12).

The County Court panel will be divided into three parts, based on the amount of the claim. In this manner a member of the bar who is not accustomed to go into the court for small fees may enroll only on the panel handling the largest claims, and a young man just starting out may go only on the lowest panel, or on all three if he chooses. See Lund, The Legal Aid and Advice Scheme, 4 Record N.Y. Ciry B.A. 77, \&4 (1949). It should also be noted that solicitors volunteer for duty on panels in their own names. But when a certificate is issued to an assistant litigant, it is in the name of the solicitor's firm so that the firm may transact the business just as if they were dealing with an ordinary ciient. Ibid.

62. Birl c1. 5 (4)-(6).

63. See Smith, Legal Aid and Advice: The Rushcliffe Report as a Land-Mlarl, 33 A.B.A.J. 445, 446 (1947). The prospect of compensation for services rendered will also attract more lawyers to participate in the plan.

64. Legal aid in criminal matters has not been considered in this Comment, but even there most compensatory provisions are inadequate. Mlany statutes speal in terms of "reasonable compensation," e.g., Ind. Star. ANn. \$9-1314 (Burns 1933); M[nss. Anzr. LAws. c. 277, $\$ 55,56$ (1932). But this phrase has been spelled out in a most unreasonable manner. See, e.g., MInN. Stat. Ann. \$611.07 (West, 1947) (\$10 per day); Mlo:it. Rev. CODES ANN. $\$ 11887$ (1935) (reasonable compensation, but not to exceed \$100 in a copital case, $\$ 50$ for felonies, and $\$ 25$ for other cases) ; OrLA. STrt. ANw. tit. 22, $\$ 1271$ (1936) ("reasonable and just" compensation in all cases, but maximum is \$25); VA. COoE Arzi. $\$ 3518$ (1942) (maximum compensation \$25). New York is perhaps the only state which 
The Bill contemplates that lawyers be paid an amount equal to $85 \%$ of that presently allowed when the case is in the House of Lords, Court of Appeal, and the High Court. ${ }^{65}$ If the case is in the county court, full scale fees and costs are to be paid. ${ }^{66}$

\section{Legal Advice}

In addition to providing assistance at the litigation stage, the British Legal Aid and Advice Bill contemplates separate facilities for obtaining legal advice. ${ }^{67}$ Undoubtedly litigation can frequently be avoided if the necessary legal advice is available and preliminary negotiations are carried out. Private legal aid bureaus in America, for instance, have been able to settle the vast majority of their cases without resorting to legal action. ${ }^{08}$

really makes a "reasonable" provision for compensation. It permits the attorney to receive personal and incidental expenses and compensation not to exceed $\$ 1000$. N.Y. CoDE CrIM. Proc. $\$ 308$.

65. Bili, 3d Schedule; REPORT $\$ 171$ (24). The 15\% deducted really represents $50 \%$ of the profit normally remaining to the solicitor after meeting his overhead expenses. The details in computing the compensation permitted to counsel are set forth in the Third Schedule of the Bill.

66. It was originally recommended that a new county court scale of costs be devised which would allow for reasonable compensation for attorneys and which would be applicable to all county court actions in which a civil aid certificate was granted, irrespective of the amount in dispute. See REPORT $\$ 171$ (25). In formulating this new scale of costs the Committee thought that where the claim was for a named amount, the defendant's solicitor should not recover more than half the claimed amount, and that the plaintiff's solicitor should not recover more than half the amount actually recovered, though the judge should have discretion to amend these limits when circumstances warranted. Sec Sumarary §23. The Committee's recommendation was not adopted, however, because it was felt that these limitations on compensation would constitute an unwarranted burden upon the participating lawyers. Hence, the Bill provides in the Third Schedule that attorneys will receive their full costs and fees in the County Courts.

67. "With us [in America] 'legal aid' means assistance to poor persons in court or" out of court and of course includes advice. In England 'legal aid' means assistance in litigation and negotiation but not advice and it includes assistance not merely to the poor but also to persons of moderate means.

"The giving of advice is called in the English plan simply 'Advice'. It does not include letter-writing or any negotiating with opposing parties or counsel. In England the office giving advice has commonly been called 'Poor Man's Lawyer." (Italics in the original). Smith, The English Legal Assistance Plan: Its Significance for Amcrican Legal Institutions, 35 A.B.A.J. 453, 456 (1949). See Brut cl. 6.

68. The following figures published by the Boston Legal Aid Society show the disposition of cases which it handled during the year 1944.

\section{Dispositions}

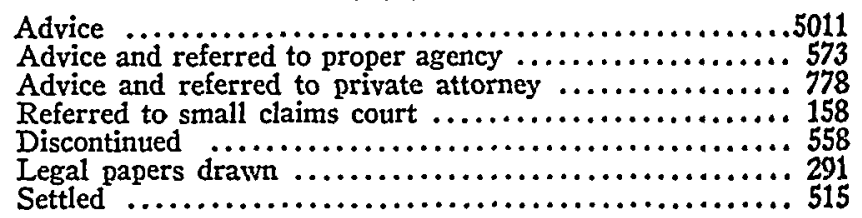


In both England and the United States free legal advice is presently provided by privately established legal aid bureaus, trade unions, local administrative officials, members of the profession who are willing to give advice gratuitously, and the like. ${ }^{69}$ To replace these facilities, the Bill contemplates the establishment of Legal Advice Centres staffed by full or part-time solicitors who disseminate advice to applicants upon payment of a small fee.70 Although no upper means limit is prescribed, legal advice may be refused where it is apparent to the solicitor that the applicant is able to engage the services of a private lawyer. ${ }^{71}$

Unfortunately, the Bill perpetuates the very narrow British conception of legal advice, by limiting the service to oral communications between solicitor and applicant. ${ }^{72}$ Failure to provide for the obvious techniques of negotiation and correspondence means that an applicant with anything more than the simplest question must meet the requirements of financial eligibility, and confer with a solicitor as if he were seeking full legal aid. Furthermore, when the work of advice is completed a detailed bill must be submitted for approval, a needlessly complicated and costly procedure. ${ }^{73}$ It would seem far more satisfactory to follow the practice of American private legal aid bureaus where legal advice is considered an aspect of legal aid rather than a separate facility.

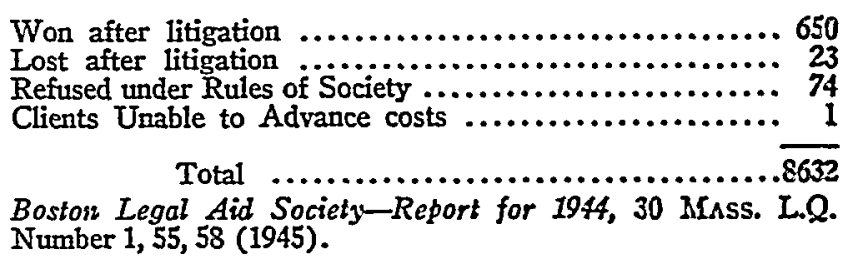

69. See REPORT 17-22.

70. BII cl. 6(2). The Report wisely recommends that these Legal Advice Centres be open in the evening, thus making them most easily available to working people $\mathrm{RE}$ PORT $\$ 178$ (2). And to make advice available in even the most rural areas, the Refort suggests that itinerant Centres be established-i.e. the Area Committee should arrange to send lawyers from its own headquarters to fixed places at fixed times. Id. at $\$ 178(5)$.

71. Bris cl. 6 (7). "Persons seeking advice will not be subject to any 'means test'. Each person will be expected to pay fifty cents for each interview but the solicitor may waive that. If the lawyer at the Legal Advice Centre believes the applicant can afford to consult a solicitor in the usual way, he will give him no advice except just that" Smith, The English Legal Assistance Plan: Its Significance for Ameriean Legal Institutions, 35 A.B.A.J. 453, 527 (1949).

72. See notes 8 and 67 supra.

73. In addition, the confined scope of legal advice may discourage capable men from serving in the Legal Advice Centres established by the Bill. It would seem wise to extend the functions of legal advice so that they are more in line with those of other social agencies. Then "such centres would aim at conciliation both in matrimonial and other disputes and would not separate the legal from the social aspect of the case." See The Report on Legal Aid, 89 SoL. J. 334, 335 (1945). The importance of cooperation with other social agencies has been recognized by American legal aid organizations. See Report of the CoAsattTeE on Retations with Soctal Agenctes to the N.A.l.A.O. (1934). 


\section{Administration of the Program}

\section{Organization}

Administration of a project having the wide scope contemplated in the English Bill will be an impressive undertaking. Accordingly the Bill has not prescribed a blueprint for detailed organization and administration. It has blocked out a broad outline, and cast the job of devising a successful plan of daily administration upon the Law Society. ${ }^{74}$ The Society will also be responsible for the state-financed Legal Aid Fund, and will be required to stumit yearly financial reports to the Lord Chancellor. ${ }^{75}$ An advisory committee, composed of laymen as well as lawyers, will be established to consult with the Lord Chancellor on the efficiency and accomplishments of the scheme. ${ }^{70}$

The Bill contemplates that England and Wales will be divided into twelve areas, each having an Area Committee consisting of approximately fifteen practising barristers and solicitors appointed by their respective professional organizations. ${ }^{77}$ The members of the Area Committee will be appointed for three years and retire in rotation, although they are eligible for reappointment. Area Committeemen will receive no salary, but will be entitled to travelling expenses and a small attendance allowance. The immediate success of the plan will depend upon the ambition and efficiency of these Committees, for they must prepare the original panels of volunteer barristers and solicitors, establish adequate facilities for legal advice, and appoint the needed local committees. ${ }^{78}$

The Area Committee will be responsible to the Law Society for all financial matters, including the collection and payment of costs.70 It must hear all appeals taken from the local committees on issues of legal eligibility to receive assistance. ${ }^{80}$ In addition, the Area Committee determines when more than one counsel shall be assigned to cases appearing before the High Court. ${ }^{81}$

Like the Area Committees, the local committees will consist of practising solicitors and barristers. ${ }^{82}$ Their main function, determining legal eligibility

74. Brtr cl. 7. The Law Society is similar to the American Bar Association, but is far more powerful in the control it exerts over the profession.

75. Bill cl. 7,8.

76. BrLI cl. 12. Members of the Advisory Committee are to serve without compensation, but will be reimbursed for travel and other expenses which they incur in the course of their duties.

77. The Rushcliffe Report originally suggested that there be eleven areas. REront $\S 171$ (3). However, the plan of the Law Society now contemplates twelve. See SumMARY $\$ 7$.

78. See Summary $\$ 7$. For more detailed description of the functions of the Area Committees see REPORT $\$ 171$ (4)-(8).

79. SuMMAary $\$ 8$; REPORT $\$ 171$ (8) (c).

80. Summary $\$ 8$. The only determination made by the Area Committee and local committee is that of the legal eligibility of an applicant. The question of financial cligibility is decided solely by the National Assistance Board. See note 23 supra.

81. SuMrarary $\$ 8$.

82. Sumarary $\$ 9$; Report $\S 171$ (9). 
for assistance, will be discharged by sub-committees composed of three to five members of the local committee. ${ }^{83}$

\section{Determining Legal Eligibility}

The problem of selecting an authority to determine the legal eligibility of applicants has been a troublesome one in the administration of legal aid. A variety of solutions has been offered. Generally speaking, this task has been performed either by lawyers, ${ }^{84}$ the court in its discretion, ${ }^{85}$ or by a separate administrative board established for the sole purpose. ${ }^{80}$ Under the British Bill the dominant role in determining eligibility is played by the practising lawyers who compose the local committees.

83. Ibid. These sub-committees will be known as "Certifying Committees" and will issue certificates which evidence the applicant's eligibility to receive legal assistance. The local committees will also be responsible for the maintenance of adequate legal aid f2cilities in their own narrow sphere and must report any problems which they encounter to the Area Committee.

84. The new English plan splits the duty of determining eligibility between a nonlawyer group, the National Assistance Board (which determines financial eligibility) and the Law Society (which determines legal eligibility). The practice in England has been for an applicant to submit his request for legal aid to the "Prescribed Officer" of the court, who would in turn submit the application to a solicitor, who would malie a report whether and on what terms the applicant ought to be admitted as a poor person. Under this system the reporting solicitor was made the judge of both financial and legal eligibility. See REPORT $\$ 8$ (b), (c). Although the exact procedure varies, private lawyers have also had the decisional power in France, League of Natrons Refort 131 et seq., and Rumania, id. at 210. Generally speaking, however, it has been rare for practising lawyers to make this decision. See Egerton, Legal Amo 58 (1945).

In the case of private American legal aid organizations the attorneys receiving the applicant determine both legal and fnancial eligibility. It has been suggested that doubtful cases should be referred to a bar association committee. See Sastr \& Bradway, TrE GrowtH of Legal-Aid Work in the United States 123 (Dept. of Labor Bull. 607, 1936).

85. This method has been the most frequent solution to the problem. See, e.g., Netheriands, IEague of Nations Report 200; Sweden, id. at 233; Venezuela, id. at 406. For discussion see Cohn, Legal Aid for the Poor: $A$ Study in Comparative Law and Legal Reform, 59 L.Q. REv. 250, $263-4$ (1943). In the United States enforcement and administration of in forma patperis statutes have similarly been left in the hands of the judge. See, e.g., Whittle v. St. Louis \& S. F. Ry. 104 Fed. 286 (81h Cir. 1900); and see statutes cited in note $S 9$ infra. For more detailed discussion of the American practice see Jacoby, Legal Aid to the Poor, 53 HARv. L. REv. 940, 961 (1940); and for a critical view of this practice, see Miaguire, Poverly and Civil Liligation, 36 Hasv. L. REv. 361, 389 (1923) (claiming that judges do not have the time or facilities to carry out this function); compare Cohn, sipra, at 267 (arguing that the court should perform this duty and that any objection of overburdening the court may be eliminated by putting the function in the hands of a master or registrar).

86. See, e.g., Denmark, League of Nations Report 114 (president of police decides); Norway, id. at 202 (MFinister of Justice decides). France (see note 84 sigra) might also be placed in this category, for there a burean de l'assistance judiciare-comrosed usually of retired judges, avocats (barristers), avonés (solicitors), notaries, court clerlis, etc-determine an applicant's eligibility for legal assistance. For the detailcd discussion of French, German, and English methods see Jacoby, Legal Aid to the Poor, 53 Hans. I. REv. 940, 963-6 (1940). 
A persuasive argument may be spelled out by opponents of lawyer-determination, on the theory that legal aid is an essential part of the administration of justice and should therefore be determined by those responsible for justice-the state or its agent, the courts. It may also be argued that lawyer-determination neglects the interest of the taxpayer and the assisted party's opponent. Especially is this true where the assisted party loses, for his opponent may then claim that the law permitted the legal profession to saddle him with costs when the profession itself had a stake in the matter. ${ }^{87}$

In defense of the British position, however, it should be noted that the state may be the other party in civil litigation and should not have the power to determine its opponents' right to assistance. ${ }^{88}$ In cases where the cost to the government would be high, there may be a tendency to deny eligibility. Furthermore, possible antagonism among the profession toward the program would be minimized by permitting lawyers themselves to determine eligibility. Lawyers have administered the private legal aid programs in the past; it would seem unwise to ignore the value of their experience by establishing some new and untried organization to handle this essential element of the plan, particularly since determination of a prima facie case requires legal training.

Although most states in this country give the judge power to determine eligibility for state assistance, ${ }^{89}$ the court has neither the time nor the facilities to carry out this function with any degree of accuracy. It is significant that the State of Washington, which has the most extensive and recent statutory provisions relating to legal aid, has made it the duty of the bar association, rather

87. See generally Egerton, Legal Aro 58-65 (1945); Cohn, Legal Aid for the Poor: A Study in Comparative Law and Legal Reform, 59 L.Q.Rev. 250, 265-6 (1943) ; Cohn, The Political Parties and Legal Aid, 8 Mod. L. Rev. 97, 106 (1945).

88. See REPORT $\S \S 128-31$. "There was almost unanimity amongst witnesses that any scheme evolved should be administered by the lawyers. Some witnesses at first suggested that there should be a State scheme or a scheme administered by local authorities, but nearly all agreed eventually that a scheme administered by the lawyers would be the best. We think that the reasons given by the Labour Party and by the Association of Municipal Corporations in their memoranda summarize the views of the various witnesses. The following is an extract from the Labour Party's memorandum:

"There are obvious objections to the State itself establishing and maintaining legal advice bureaux. Not the least of these objections is that the State itself is directly or indirectly affected by many of the claims upon which such bureaux would have to advise. Nor, in the opinion of the Labour Party, is it desirable that the local authorities should be entrusted with the duty of establishing and maintaining legal advice burcaux. . . . Differences, political or otherwise, might well arise were a local authority to be held responsible, directly or indirectly, for the advice given in any particular matter. Morcover, it has to be borne in mind that many local authorities, particularly those concerned with passenger transport undertakings, are themselves frequently parties to litigation." $I d . \S 129$.

89. See, e.g., ARk. Stat. Anv. \$27-403 (1947) ; Colo. Stat. Ann. c. 43, §22 (Supp. 1947) ; Ill. Ann. Stat. c. 33, $\$ 5$ (Supp. 1948); Ind. Stat. AnN. \$2-211 (Burns, 1933); Ky. Rev. Stat. $\$ 453.190$ (1948); La. Gen. Stat. Ann. \$1400 (1939); Mich. Stat. Awn. $\$ 27.738$ (Henderson, 1936); Mo. Rev. Stat. ANN. $\$ 1404$ (1939); W. VA. Codv $\S 5853$ (1943). 
than the judge, to determine eligibility. ${ }^{90}$ As a check of the bar's exercise of this power, however, it may be wise to give the courts discretion to deny compensation to any attorney who abuses the profession's favored position by participating in an obviously ill-founded action. ${ }^{01}$

\section{Financing the Program}

A financial memorandum attached to the Bill estimates that establishment and maintenance of the necessary administrative machinery would cost ap-

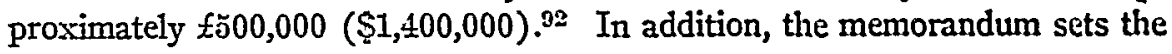

90. Under the Washington plan the board of county commissioners is given the power formally to declare the existence of a demand for legal aid. This declaration must indicate the amount of county funds available for financing a legal aid bureau. The State Bar Association must then, within sixty days, create a legal aid bureau having as a director an attorney residing in that county. Supervisory powers over all the legal aid bureaus are given to the Board of Governors of the State Bar Association. This includes the determination of legal eligibility for assistance. See WaSz. Rev. Stat. Arri. \$10007207 (Remington, 1940). The statute contemplates that county funds are to be disbursed by the bar association, and provides that no attorney's fees are to be paid by assisted litigants, although fees and court costs collected from third parties become part of the bureau's fund for operating expenses. A nominal (fifty cents) registration fee is demanded of all applicants, and no legal aid will be given in cases which a private attorney would handle on a contingent fee. See WASH. Rev. Stat. Avr. $\$ \$ 10007-209$; 10007-210 (Remington, 1940). For a discussion of the Washington plan see Jacoby, Legal Aid to the Poor, 53 Harv. I. Rev. 940, 947-9 (1940). And see Luccock \& Kaminoff, A Gencral Reviczy of the Work of the 1939 Washington Legislature, 14 WAsrr. L. REv. 181, 194 (1939); Smith, Interest of the Anerican Bar Association in Legal Aid Worh, 205 Asisuls 108, 112 (1939). Allowing the State Bar Association to administer public funds may reduce the possibility of political influence corrupting the expenditure of these monies. See Sartre, Justice and the Poor 186 (3d ed. 1924); Sartra \& Bradwax, Tre Growtr or LEGAI-Am Work IN IHE UNITEd STATES 136 (Dept. of Labor Bull. 607, 1936). But in comparing the Washington plan with that of another state, it must be remembered that the Washington Bar Association is closely integrated, state-wide, and incorporatedwhile that of many states is an informal organization having only local influence. See Beckwith, Sturveying the Need for Legal Aid, 205 Awarss 9, 13 (1939); Gorsuch, Interest of State Bar Associations in Legal Aid Work, id. at 118.

91. This protective device is employed in Sweden with apparent success. Ser Garrison, Legal Serwice for Low Incone Groups in Sweden, 26 A.B.A.J. 215, 216 (1940). The fact that such a simple check is effective is most significant, especially since Swedish legal aid provisions enable litigants to go through a law suit without any personal expense. To qualify for legal aid an applicant need only make a statement, confirmed by a public official or other well known person, that he can't pay for the conduct of the litigation. Id. at 215. See EgERToN, LegaI AIn 45-6 (1945). Under this system more than half of the total population of Sweden is eligible for legal aid. Garrison, supra, at 218. Perhaps the success of the Swedish plan is in large measure due to the healthy competition between private practitioners and the legal aid bureau for the privilege of assisting the needy litigant. See Maguire, Legal Aid in 9 ENcy. Soc. Scr. 319, 322 (1931). For a most enlightening comparison between the Stockholm Public Institute for Legal Assistance and the Milwaukee Legal Aid Bureau see Garrison, stspra, at 218-20, 293-4.

92. See Financial Memorandum, incorporated as part of the Bill. The Rusheliffe Committee had earlier put this figure at $£ 200,000(\$ 560,000)$. REront $\$ 190$. 
total annual expenditures when the scheme is in full operation at $\pm 4,370,000$ $(\$ 12,236,000) .93$ Of this amount it is expected that $£ 2,370,000(\$ 6,636,000)$ will be met in contributions received ${ }^{94}$ and costs recovered. ${ }^{.5}$

Since no complete and authoritative study on a nation-wide basis has ever been made for the United States, it is difficult to estimate the cost of a comprehensive legal aid program for this country. Admittedly, great expense will be incurred if aid is given to those who can pay part of the cost, ${ }^{00}$ and heretofore most programs have excluded this group. But if those who object to including these litigants also give credence to the principle of equal protection, they are forced into advocating that either the government or private sources finance the full costs of litigation. To impose this burden on the govern-

93. See Financial Memorandum, incorporated as part of the Bill. Paragraph 9 of the Financial Memorandum estimates the total annual expenditure breakdown to be as follows:

Cost of administration (Law Society Area and Local Committees, Legal

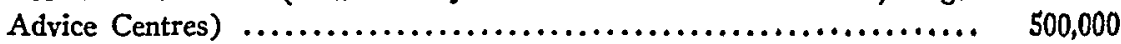

Legal Advice in England and Wales .............................. 200,000

Legal Advice Overseas ..................................... 100,000

Divorce Cases where the amount of contribution is under $\$ 10 \ldots \ldots \ldots \ldots . .300,000$

Other litigation $\ldots \ldots \ldots \ldots \ldots \ldots \ldots \ldots \ldots \ldots \ldots \ldots \ldots \ldots \ldots \ldots \ldots \ldots \ldots \ldots . . \quad 3,000,000$

Cost to National Assistance Board $\ldots \ldots \ldots \ldots \ldots \ldots \ldots \ldots \ldots \ldots \ldots \ldots \ldots \ldots$. 20,000

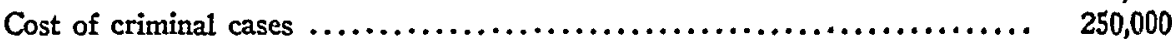

$4,370,000$

94. Each assisted person must contribute towards all costs from his income and capital above the statutory exemption. See note 23 supra.

95. These are costs recovered from the unsuccessful opponents of assisted litigants. See notes 48 and 50 supra.

96. It is interesting to note, however, that Sweden, which has long fostered a program comparable to that proposed in the British Bill, has spent only .5 million kroner, or $1 / 360$ th of its total expenditures for social purposes, in order to meet the costs of such an undertaking. See Egerton, Legni Arp 45-6 (1945).

No rational argument can be advanced in support of the proposition that lawyers alone should bear the full costs of any legal aid program. The days of large private donations to support legal aid are gone. (For some examples of early American methods of privately financing legal aid see MAGuire, THe LANCE of JUSTICE 253-68 (1928).) It would therefore seem that the government should undertake the responsibility of financing legal aid to the degree that such a program is not self-liquidating. Government financing should not endanger the independence of the legal profession. As Egerton has observed, "Many public services are dependent on Government grants but are free from interference within the proper sphere of their activity.... The integrity of the organizations and a right of inspection are the sole guarantees that the money will be properly applied.... There is no reason to think that the amount of the grant which would be required would alarm a Treasury accustomed to the expenditures of the last few years and committed to a large expenditure on social services in the future." EGERTON, supra, at 130.

The possibility of using some form of either voluntary or compulsory insurance to finance a legal aid program has been considered. Generally speaking, however, this has been deemed an inappropriate use for insurance; the risk of litigation is not suf- 
ment goes even further than the British Bill.97 And to suggest that private sources undertake full financing is to ignore their inadequacies under the much more limited program which exists today. 98

If state-supported legal aid were adopted in the United States, federal grants-in-aid would probably provide the best means for sustaining the scheme. ${ }^{99}$ This technique has already been used successfully to cope with a host of problems concerning the economic underprivileged ${ }^{100}$ and would seem the most opportune method of integrating a federal-state-local program.

\section{ConcLusion}

The British government and legal profession have concluded that the need for legal aid demands government action. So far in the United States this problem has been considered beyond the province of either the state or national government. It has rather been left to the philanthropy of private citizens and the sacrifice of public-spirited lawyers. In consequence, most lawyers are in competition to serve less than $10 \%$ of the population-those able to pay the costs of litigation. A great untapped demand and need for low cost legal services remains. Fewer than $2 \%$ of those earning less than $\$ 2,500$ ever consult lawyers. ${ }^{101}$

The British have come to grips with this problem. Their solution, though basically sound, may not be fully applicable to our federal form of government, where court organization varies from state to state. ${ }^{102}$ No categorical solution may be offered to solve the individual problems raised in the several states. ${ }^{103}$ These facts do seem clear, however. Existing in forma panporis statutes are wholly inadequate. ${ }^{104}$ Private funds are not able to meet the demand for legal

ficiently high to warrant an individual's budgeting for the possibility. For further details see Egerton, Legal Am 128-9 (1945); Jacoby, Legal Aid to the Poor, 53 Hasv. I. Rev. 940, 972-3 (1940); Stone, Certain European Legal Aid Offices, 25 Calr. L. Rev. 52,60 (1936).

97. EGERTON, IEGAI AID 127 (1945).

98. See notes 6 and 7 sipra.

99. See Elson, The Rushcliffe Report, 13 U. of CHI. L. REv. 131, 143 (1946).

100. Among the problems which have been attacked by means of the grant-in-aid are public housing, education, relief, old age assistance, maternity problems, assistance to the blind, and assistance to physically and mentally handicapped children.

101. Elson, supra note 99, at 141-2. Also see Report of the Special Commiltec on Legal Service Butreaus, 66 A.B.A. Rep. 321 (1941).

102. Court costs similarly vary as does the prevalence of certain types of actions.

103. The type of legal aid organization will depend entirely on loeal need, community preference, and a willingness to support the enterprise. In any case, all legal aid bureaus should operate in cooperation with other social service agencies, and should provide a quality of service equal to that of a private law office, for otherwise the principle of equal protection is a meaningless platitude. See Browrzu, WaEn Your Client NEeds a Lawyer 2.

104. "The fact is . . . that this form of action, even when it legally exists, contributes little or nothing toward the solution of the problem of bringing justice within the reach of the poor." Wirloughisy, Painctples of Judicial Adarinistantion 575 (1929). For 
services, and these funds are steadily decreasing. Institutional arrangements such as small claims courts and workmen's compensation boards can at best meet only a small part of the need. If we are to turn the present fiction of equal protection into a reality, it is the duty of the government to provide adequate facilities which will enable all citizens to obtain necessary legal assistance. At the same time it is of vital importance that the legal profession be left reasonably free of government control.

A thorough study should be made in the United States to ascertain the extent and variety of the need for legal services. ${ }^{105}$ In cooperation with existing private facilities and the state bar associations, determinations should then be made as to the institutional arrangements best suited to provide legal aid and advice in each state. These steps would not be inconsistent with our political philosophy. Rather they would lead to a democratic solution designed to remedy a national need, and would create greater respect for law and the lawyer.

the view that the present fragmentary in forma pauperis statutes should bo entircly scrapped, see Maguire, Poverty and Civil Litigation, 36 HARv. L. RFv. 361, 390 (1923).

105. The Survey of the Iegal Profession, under the direction of Reginald Heber Smith, Esq., is now engaged in a vast survey of lawyers and the law-and problems related thereto. It is to be hoped that this undertaking will shed enough light to enable the legal profession and the government to take constructive steps to improve our legal aid facilities. For a description of this project see Porter, Surveying the Legal Profession: in Whose Interest, How, and to Test What Hypotheses?, 32 J. AM. JUd. Soc'y 134 (1949). 